\title{
Evaluation of General Clinicopathological Features in Patients with Esophageal Cancer and Determination of Factors Affecting Prognosis
}

\section{Özefagus Kanserli Hastalarda Genel Klinikopatolojik Özelliklerin Değerlendirilmesi ve Prognoza Etki Eden Faktörlerin Belirlenmesi}

\author{
Fatma Buğdaycı Başal ${ }^{1}$, Ferit Aslan ${ }^{2}$, Erkan Erdur ${ }^{3}$, İrem Bilgetekin ${ }^{1}$, Berna Öksuzoglu $^{1}$, Umut Demirci ${ }^{4}$ \\ ${ }^{1}$ SBÜ, Dr. A.Y. Ankara Onkoloji E.A.H., Medikal Onkoloji Kliniği, Ankara \\ ${ }^{2}$ Yüksek İhtisas Üniversitesi, Ankara-Batıkent Medical Park Hastanesi, Medikal Onkoloji Kliniği, Ankara \\ ${ }^{3}$ SBÜ, Gazi Yaşargil E.A.H., Medikal Onkoloji Kliniği, Diyarbakır \\ ${ }^{4}$ Üsküdar Üniversitesi, Ankara Memorial Hastanesi, Medikal Onkoloji Kliniği, Ankara
}

Dergiye Ulaşma Tarihi:30.06.2020 Dergiye Kabul Tarihi:13.07.2020 Doi: 10.5505/aot.2020.68335

\section{ÖZET}

GİRIŞ ve AMAÇ: Bu çalışmada dahil edilme kriterlerine uygun 182 özefageal kanserli hastanın tek merkez gözlemsel verisinin değerlendirilmesi, klinik ve demografik özelliklerinin incelenmesi ve multimodal tedavi dahil diğer prognostik faktörlerin analizi amaçlanmıştır.

YÖNTEM ve GEREÇLER: Araştırma kapsamında, Ocak 2010-Aaralık 2019 tarihleri arasında özefagus kanseri tanısı alan 182 hasta çalışmaya dahil edilmiştir. Hastaların demografik, klinik, patolojik özellikleri ile tedavi ve yan etki bilgilerine dosya kayıtlarından ulaşılmıştır. Sağkalım analizleri Kaplan- Meier testi ile, tek değişkenli analizler Log-Rank testi ile ve çok değişkenli analizler Cox-Regresyon testi ile değerlendirilmiştir

BULGULAR: Hastaların en sık görülen histopatolojik tipi skuamoz hücreli kanser (n: 153, \% 84.1) ve en sik tümör lokalizasyonu alt uçta bulunmaktadır. Uygulanan sistemik tedaviler adjuvan kemo(radyoterapi) \%6, neoadjuvan kemoterapi \%2.7, neoadjuvan kemoradyoterapi \% 30.8 ve definitif kemoradyoterapi \%37.9 olarak saptanmıştır. Uzak metastatik hastalar da çalışma grubuna dahil edilmiştir. Tek değişkenli analizlerde diferansiyasyon derecesi, multimodal tedavi varlığı, rezeksiyon tipi, neoadjuvan tedavi yanıtı, tanıda metastaz varlığı açılarından genel sağkalım (GS) ve progresyonsuz sağkalım (PS) farkı saptanmıştır $(p<0.05)$. Çok değişkenli analizlerde cerrahi sınır negatifliğinin progresyon riskini 3.4 kat azalttığ $(\mathrm{p}<0.001)$, lenfovasküler invazyon (LVI) varlığının da progresyon riskini 1.9 kat arttırdığı $(\mathrm{p}=0.004)$ gözlenmiştir. Genel sağkalım açısından ise tek prognostik faktörün cerrahi sınır negatifliği olduğu gözlenmiş ve ölüm riskini 2.4 kat azalttığı $(\mathrm{p}<0.001)$ saptanmıştır.

TARTIŞMA ve SONUÇ: Sonuç olarak tek merkeze ait gözlemsel veriler sunulmuş ve oluşturulan alt gruplarda tedavi yanıtı, rezeksiyon tipi, histolojik alt tip ve tümör lokalizasyonu ile ilgili literatür ile uyumlu bulgular elde edilmiştir. Prognostik faktörler açısından LVİ ve cerrahi sınır negatifliğinin kuvvetli prognostik faktörler olduğu gösterilmiştir

Anahtar Kelimeler: özefagus kanseri, gözlemsel çalışma, prognoz

\begin{abstract}
INTRODUCTION: In this study, it was aimed to evaluate the single-center observational data of 182 patients with esophageal cancers, to examine their clinical and demographic features and to analyze other prognostic factors including multimodal treatment METHODS: Within the scope of the study, medical records of 182 patients diagnosed with esophageal cancer between January 2010 and December 2019 were included. The demographic, clinical, pathological features, treatment and side effects of the patients were obtained from the file records. Survival analyzes were evaluated by the Kaplan-Meier test, univariate analyzes by the Log-Rank test, and multivariate analyzes by the CoxRegression test

RESULTS: The most common histopathological type is squamous cell cancer (n: 153, 84.1\%) and the most common tumor localization in the patients is located at the lower part. Systemic treatments applied were adjuvant chemo (radiotherapy) $6 \%$, neoadjuvant chemotherapy $2.7 \%$, neoadjuvant chemoradiotherapy $30.8 \%$ and definitive chemoradiotherapy $37.9 \%$. Distant metastatic patients were also included in the study group. In univariate analysis, the difference in overall survival (OS) and progression-free survival (PFS) was determined in terms of differentiation, presence of multimodal therapy, resection type, neoadjuvant treatment response, and presence of metastases ( $\mathrm{p}<0.05$ ). In multivariate analysis, it was observed that surgical margin negativity decreased the progression risk by 3.4 times $(\mathrm{p}<0.001)$, and the presence of lymphovascular invasion (LVI)
\end{abstract}




\section{Orijinal Makale}

increased the risk of progression by 1.9 times $(p=0.004)$. In terms of overall survival, it was observed that the only prognostic factor was surgical margin negativity and decreased the risk of death by 2.4 times ( $\mathrm{p}<0.001)$.

DISCUSSION AND CONCLUSION: As a result, observational data belonging to a single center were presented and findings compatible with the literature regarding the treatment response, resection type, histological subtype and tumor localization were obtained. In terms of prognostic factors, LVI and surgical margin negativity have been shown to be strong prognostic factors.

Keywords: esophageal cancer, observational study, prognosis

\section{GİRIS}

Özefagus kanseri dünyada 8. siklıkta görülen kanser olup; kansere bağlı ölümler arasında 6 . sıradadır (1). İleri evrede tanı konması nedeniyle yüksek mortalite ve morbiditeye sahiptir $(1,2)$. Tan1 ve tedavideki ilerlemelere rağmen 5 yıllık sağkalım \%15-20 arasındadır (3). Etnik köken, genetik faktörler ve yaşam tarzı özefagus kanseri gelişiminde rol oynar (4). İki histolojik alt tipi adenokarsinoma ve skuamoz hücreli karsinomdur ve bu iki histolojik tip özefagus kanserlerinin \%95'ini oluşturur (5). Son y1llarda adenokarsinomanın insidansı artış gösterse de halen en sık görülen tip skuamoz hücrelidir (2). Adenokarsinom ve skuamoz hücreli kanser tümör lokalizasyonu ve etyoloji açısından farklıdır. Alkol ve sigara skuamoz hücreli için risk faktörü iken reflü, Barret özefagusu, obezite ve sigara adenokarsinom için risk faktörleridir (6). Skuamoz hücreli epitelden kolunmar epitele metaplastik transformasyonun gözlendiği Barret özefagusu adenokanser riskini 30 ila 40 kat arttırır (7). Skuamoz hücreli kanser 60-70 yaşları arasında ve siyahi 1rkta daha sık görülürken adenokanser 50-60 yaşları arasında ve beyaz rrkta daha çok görülür (2).

Özefagus kanseri erken evrelerde siklıkla asemptomatik iken ileri evrelerde kilo kaybı, progresif yutma güçlüğü, odinofaji, gögüs ağrisı ve medikal tedaviye cevap vermeyen özefageal yanma ile kliniğe prezente olabilir $(2,8)$. Adenokarsinomlar alt uç özefagusta artış gösterirken torasik özefagusta hem skuamoz hücreli hem adenokanser birlikte artmaktadır (9). Skuamoz hücreli kanser ile prezente servikal özefagusta kanser görülme riski \%5-6 oranında artış göstermiştir (8). Klinik

evreleme için konvansiyonel bilgisayarlı tomografi (BT), pozitron emisyon tomografi (PET), endoultrasonografi (EUS) kullanılır. Lokorejyonel lezyonları değerlendirmek için konvansiyonel BT, uzak metastazları saptamak için PET BT daha duyarlıdır ve birlikte kullanıldığında duyarlılık ve özgüllük artar
(10). Uzak metastazı olmayan hastalarda EUS, tümör invazyonu ve lenf nodu tutulumu açısından yararlıdır $(2,11)$.

Potansiyel olarak rezeke edilebilen lokalize tümörlerde primer tedavi cerrahidir. Lokal ileri tümörlerde ise perioperatif kemoterapi ya da kemoradyoterapinin tek başına cerrahiye göre sağkalım avantajı mevcuttur $(2,12)$. Preoperatif kemoradyoterapi tümör derecesini küçülterek (özellikle patolojik tam yanıt) ve cerrahi sınır negatifliği oranını arttırarak sağkalım avantajları sağlamaktadır (13-20). Rezeksiyon tipi en önemli pognostik faktörlerden biridir ve cerrahi sınır negatifliği sağlanamayan operasyon küratif değildir (21). Pivotal bir çalışma olan CROSS çalışmasında preoperatif kemoradyoterapi ile yalnızca operasyona göre 2 kat sağkalım (49.4 vs 24 ay) elde edildiğini göstermiştir (13). Neoadjuvan radyoterapinin neoadjuvan kemoradyoterapi kadar etkili olmadığı bilinmektedir (21). Özefageal skuamoz hücreli kanserde neoadjuvan kemoradyoterapi neoadjuvan kemoterapiye göre etkili cerrahi sınır yanında sağkalım avantajı sağlamaktadır. Özefageal adenokarsinomda ise hem neoadjuvan kemoterapi hem de neoadjuvan kemoradyoterapi anlamlı olarak sağkalımı arttırmaktadır $(13,21)$. Skuamoz hücreli kanserde neoadjuvan kemoradyoterapiye cerrahi eklemenin definitif kemoradyoterapiye göre lokal kontrolü arttırsa da sağkalımı etkilemediği gösterilmiştir (22). Operasyon sonras1 performansı kötüleșen hastanın adjuvan kemoradyoterapi tedavisini tamamlayabilmesi zor olmaktadır fakat son yillarda cerrahi ve radyoterapideki gelişmeler ile uygulanması daha kolay hale gelmiştir (12). Yapılan çalışmalarda tek başına cerrahi tedaviye göre adjuvan kemoradyoterapinin anlaml 1 uzun sağkalımlar elde ettiği gösterilmiştir $(23,24)$. Preoperatif kemoradyoterapi sonrası opere olan hastalarda adjuvan tedavi tartışmalı olsa da yüksek hasta sayılı $(>10.000)$ iki retrospektif çalışmada rezidü nodal hastalık varlığında sağkalım avantajı gösterilmiştir $(25,26)$. 


\section{Orijinal Makale}

Yalnızca cerrahiyi içermeyen, perioperatif kemoterapi ve/veya radyoterapinin de yer aldığ1 multimodal tedavilerle özefagus kanser tedavisinin klinik yararlanımı arttırılmıştır (19).

Hastaların \% 75'i ileri evrede karşımıza çıkar ve küratif tedavi alamaz. Uzak metastazlı hastaların 5 yıllık sağkalımı \% 5'tir. Kemoterapi, özefageal stent, brakiterapi, jejunostomi, gastrostomi tüpü gibi yaklaşımlar palyasyon amaçlı uygulanabilir (2).

Çalışmamızda merkezimize başvuran ve sistemik tedavisine devam eden dahil edilme kriterlerine uygun 182 özefageal kanserli hastanın tek merkez gözlemsel verisinin değerlendirilmesi, klinik ve demografik özelliklerinin incelenmesi ve multimodal tedavi dahil diğer prognostik faktörlerin analizi amaçlanmıştır.

\section{MATERYAL METOD}

Araştırmamız Ocak 2010- Mayıs 2020 tarihleri arasında Sağlık Bilimleri Üniversitesi Dr. Abdurrahman Yurtaslan Ankara Onkoloji Eğitim ve Araştırma Hastanesi medikal onkoloji kliniğinde gerçekleştirilen retrospektif tipte bir araştırmadır. Çalışmanın gerçekleştirilebilmesi için etik kurul onayı ve gerekli izinler alınmıştır (07.04.20 tarihli, 91 numaral1).

Araştırma kapsamında, Ocak 2010- Aralık 2019 tarihleri arasında özefagus kanseri tanısı alan 360 hastanın tıbbi kayıtları incelendi ve 182 hasta çalışmaya dahil edildi. Çalışmaya özefagus alt uçta adenokanser histolojisinde ve HER2 pozitif hastalar dahil edilmedi. Ayrica takip ve tedavisine kliniğimizde devam etmemiş olan, gerekli tıbbi bilgilerine ulaşılamayan, en iyi destek tedavi dışında tedavi almamış olan hastalar da çalışma dışı bırakıldı. Gastroözefagial bileşke düzeyinde adenokanser histolojisine sahip hastaların endoksopi raporları gözönüne alınarak "özefagus alt uç adenokanseri" şeklinde raporlanan hastalar çalışmaya dahil edildi. Hastalarla ilgili temel değerlendirmeler için yaş, cinsiyet, aile öyküsü, kronik alkol ve sigara kullanımı, komorbidite varlığ1, performans skoru, tümör lokalizasyonu, klinik ve patolojik evre, histopatolojik tip, derece (grad), cerrahi tedavi varlığı, rezeksiyon tipi (R0; cerrahi sınır negatif, R1; mikroskobik cerrahi sınır pozitif), metastatik lenf nodu sayıs1, kemoterapi ve radyoterapi bilgileri, kombinasyon tedavi bilgileri, HER2 (Human Epidermal Growth Factor Receptor 2) durumu, perinöral invazyon (PNI) ve lenfovasküler invazyon (LVİ) varlı̆̆1, metastaz varlığı, tedavi öncesi ve sonrası PET (Pozitron Emisyon Tomografi) ve endoultrasonografi (EUS) çekim varlığ1, kemoterapi yan etkileri, progresyon ve sağkalımla ilgili bilgiler tıbbi dosya kayitlarından incelendi.

Hastalarin performans durumu dosya kayitlarında ECOG (Eastern Cooperative Oncology Group) performans skoru olarak mevcuttu. Hastaların klinik ve patolojik evrelemeleri geriye yönelik olarak AJCC 8'e (American Joint Comitee on Cancer) göre yapıldı. Hastaların aldıkları tedaviler incelendiğinde neoadjuvan tedavi almadan sadece opere edilen hastalar, neoadjuvan kemo(radyoterapi) alan hastalar, definitif kemoradyoterapi uygulanan ve metastatik hastalar mevcuttu. $\mathrm{Bu}$ grupların gözlemsel verilerinin değerlendirilmesi yanısıra hastalar içinde multimodal tedavi alanlar ve almayanlar şeklinde 2 alt grup oluşturuldu. Neoadjuvan ve/veya adjuvan kemo(radyoterapi) alan ve opere edilen hastalar multimodal grupta sinıflandırılırken perioperatif sistemik tedavi almayan ve metastatik hastalar bu sinıflamadan ayrı tutuldu. Definitif kemoradyoterapi verilen tüm hastalara en az 50 Gy radyoterapi verilmiştir. Tedavi yan etkileri dosya ve sistem kayıtlarına göre elde edildi. Dosya kayıtlarında yazilmayan yan etkiler "yok" olarak verilere eklendi.

Hastaların sağkalım verileri için progresyon, ölüm ve son kontrol tarihleri dosya ve sistem kayıtlarından elde edildi. Progresyonsuz sağkalım; tanı tarihi ile ilk progresyon görülen tarih ya da ölüm tarihi arasındaki süre olarak kabul edildi. Progrese olmayan hastaların son kontrol tarihleri yazıldı. Genel sağkalım; tanı tarihi ile ölüm tarihi arasındaki süre olarak tanımlandı. Takip süresi; tanı tarihi ile son kontrol tarihi arasındaki süre olarak hesaplandi.

Tüm analizler SPSS v18 (SPSS Inc., Chicago, IL, USA) programında yapıld1. Analizlerde yaş, cinsiyet, sigara ve alkol kullanımı, lokalizasyon, diferansiasyon, tedaviye yanit, rezeksiyon tipi, PNİ ve LVİ 


\section{Orijinal Makale}

varlığ1, tedavi yöntemi, tanıda metastatik hastalık varlığı prognostik faktör olarak incelendi. Sağkalım analizleri Kaplan-Meier metodu ile gerçekleştirildi. Sağkalım sürelerinin gruplar arası karşılaştırmaları LogRank testi ile yapıldı. Çok değiş̧kenli analizde, tek değişkenli analizlerde belirlenen olası faktörler kullanılarak sağkalımı öngörmedeki bağımsız etkenler geriye doğru seçim yöntemi ile Cox regresyon analizi kullanılarak incelendi. Sonuçlar \% 95'lik güven aralığında ve anlamlilik $\mathrm{p}<0.05$ düzeyinde değerlendirildi.

\section{BULGULAR}

Çalışmamızda ortalama yaş 56.5 (aralık 17-86) olup çoğunluğu erkek olan (n:110, 60.4\%) hastaların \% 57.6'sinda sigara, \% 7.7'sinde kronik alkol kullanım hikayesi mevcuttu. Ailesinde malignite ökyüsü olan hasta sayısı 50 (\% 27.5), komorbid hastalı̆̆1 olan vaka sayıs1 49 (\% 26.9; en sik hipertansiyon \% 48.9) olarak saptand1. En s1k görülen histopatolojik tip skuamoz hücreli kanser (n:153, \% 84.1) ve en s1k tümör lokalizasyonu alt uçta (n:113, $62.1 \%$ ) görüldü. Tümör lokalizasyonuna göre histolojik özelliklere bakıldığında; üst özefagusta 1 (\%3.7) hasta adenoskuamoz, 26 (\%96.3) hasta skuamoz hücreli histolojiye sahipti. Orta özefagusta $1 \quad(\% 2.3)$ hasta adenoskuamoz, 2 (\%4.7) hasta adenokarsinom ve 39 (\%93) hasta skuamoz hücreli kanser histolojisinde idi. Alt uç tümörlerinde ise 2 (\%1.7) hasta adenoskuamoz, 23 (\%20.3) hasta adenokarsinom ve 88 (\%78) hasta skuamoz hücreli idi. Tüm seviyelerde baskın histolojik alt tip skuamoz hücreli kanser olarak saptand. Adenokarsinomlar en s1k alt uçta (\%92) gözlendi.

Tümör derecelendirmesinde en fazla oranda orta derece diferansiye (n:95, \% 52.2) tümör mevcuttu. HER2 pozitifliği histolojik tipten bağımsız sadece 31 (\% 17) hastada biliniyordu. Tüm alt uç tümörlerinde HER2 değerlendirmesi yapılmamıştı. Tümör evrelemesi için kullanılan görüntüleme yöntemlerine bakıldığında tedavi öncesi PET BT çekim oranı \% 89.6 iken EUS çekim oranı $\% 7.1$ olarak saptand1. Bilgisayarlı tomografi tüm hastalara uygulanmıştı.

$$
\text { Mevcut görüntülemeler }
$$

1şı̆̆ında hastaların tedavi öncesi klinik evrelemesine bakıldığında evre 2 (\% 6.6), evre
3 (\% 75.8), evre 4 (\% 17.5) hastalar mevcuttu. Hastaların 21'i (\% 11.5) herhangi neoadjuvan tedavi almadan opere edilmişti. Adjuvan kemo(radyoterapi) 11 (\% 6), neoadjuvan kemoterapi $5 \quad(\% \quad 2.7)$, neoadjuvan kemoradyoterapi $56 \quad(\% \quad 30.8)$, definitif kemoradyoterapi $69 \quad(\% 37.9)$ ve sadece radyoterapi verilen 5 (\% 2.7) hasta ve tanida metastatik olan 29 (\% 15.9) hasta mevcuttu. Neoadjuvan kemoterapi alan 3 hasta takibinde neoadjuvan kemoradyoterapi de almıştı. Hastaların klinik ve demografik özellikleri Tablo 1'de özetlenmiştir.

Hastalar multimodal tedavi varlığına göre alt gruba ayrildığında neoadjuvan ya da adjuvan kemo(radyoterapi) alan ve opere olan yani multimodal tedavi uygulanan hasta sayıs1 63 iken ( $\%$ 34.6) multimodal tedavi uygulanmayan 86 (\% 47.3) hasta mevcuttu. Multimodal tedavi almayan grupta definitif kemoradyoterapi alan ya da sadece cerrahi uygulanan hastalar mevcuttu. Sadece radyoterapi verilen ve tanıda metastatik hastalar (n:33, \%18.1) bu alt siniflamaya alınmadi. Neoadjuvan kemoradyoterapi için tercih edilen kemoterapi kombinasyonu öncelikle karboplatin/paklitaksel (n:45, \% 80.3) iken definitif tedavide tercih edilen kemoterapi kombinasyonu öncelikle sisplatin/5 FU (n:46, \% 66.6) idi. Her iki tedavide bu iki kemoterapi kombinasyonu uygulanmıştı. Yan etkiler açısından bulant1-kusma, nötropeni, trombositopeni, diare, nefrotoksisite, hepatotoksisite, mukozit-stomatit ve oral alım bozukluğu değerlendirildi (Tablo 2).

Neoadjuvan tedaviye yanitlara bakıldığında tam yanıt (\% 44.8) ve k1smi yanıt (\% 43.1)yanında minimal ya da yanıt alınamayan (\% 12.1) hastalar da mevcuttu. Yeni patolojik evrelemesi elde edilen 58 hastanın 34'ünde (\% 58.5) (yp)evre 1, 7'sinde (\% 12) (yp)evre 2, 17'sinde (\% 29.5) (yp)evre 3 idi. Yeni patolojik evresi 3 olan hastalar tedaviye yanıtsız değildi. Opere edilen tüm hastaların prognoz açısından önemli patolojik özelliklerine bakıldığında \% 16.5 (n:13) LVİ, \% 11.4 (n:9) PNI, \% 8.9 (n:7) mikroskobik cerrahi sinır pozitifliği (Tip 1 rezeksiyon- R1) saptand1.

Multimodal tedavi varlığına göre oluşturulan iki alt grupta; cinsiyet, sigara ve kronik alkol kullanımı, komorbidite ve ailede malignite varlığ 1 , preklinik evre ve histolojik tip açısından fark saptanmadı. 


\section{TURCICA Orijinal Makale}

Tümör lokalizasyonu multimodal tedavi alanlarda anlamlı şekilde daha çok alt uçta iken $(\mathrm{p}<0.001)$, tümör derecesi anlamlı olarak multimodal tedavi almayanlarda daha yüksekti ( $\mathrm{p}=0.014$, Tablo 3).

Median 12.7 aylık (IQR: 4.26-

38) takipte tüm grubun genel PS süresi 16.5 ay (aralık 12.1-21) ve toplam GS süresi 28.8 ay (aralık 23-34.6) olarak bulundu. Tek değişkenli analizlerde diferansiyasyon derecesi, multimodal tedavi varlığı, rezeksiyon tipi, neoadjuvan tedavi yanıtı, tanıda metastaz varlığı açılarından GS ve PS farkı saptandı $(\mathrm{p}<0.05$, Figür 1 ve 2$)$. Tablo 4 ve 5 'te gösterildiği gibi kötü diferansiyasyon, mikroskobik cerrahi sınır varlığı, tanıda metastatik hastalık PS ve GS'1 azaltırken, neoadjuvan tedaviye yanitin olmasi,

Tablo 1: Hastaların genel demografik ve klinik özellikleri

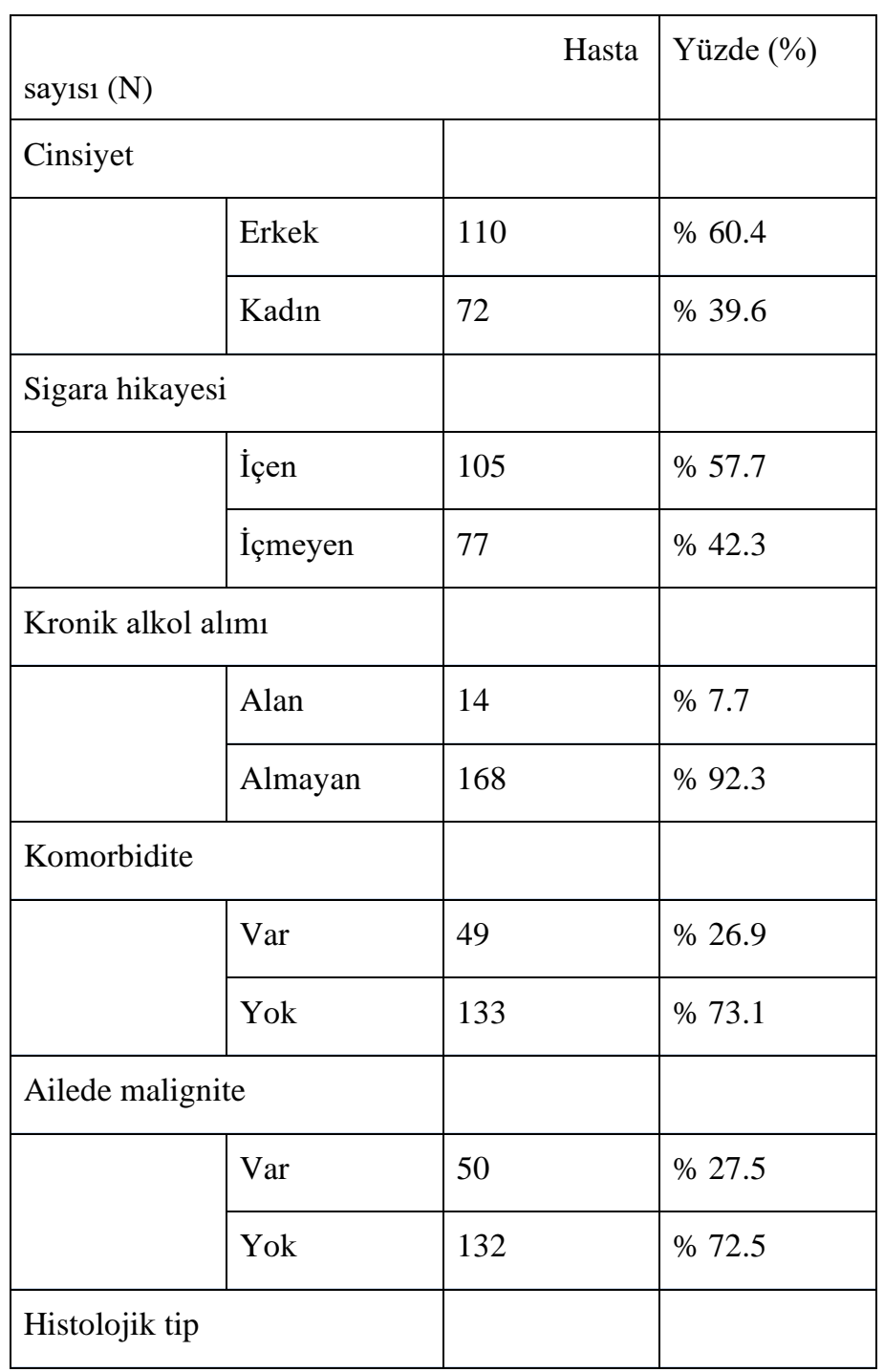

multimodal tedavi varlığı sağkalımları uzatmakta idi. Kadın cinsiyet GS'1 arttıran, LVİ varlığı da PS'1 azaltan faktörler arasında bulundu (Figür 3). Tek değişkenli analizlere göre belirlenen faktörler çok değişkenli analizlerde incelendiğinde; cerrahi sınır negatifliğinin sağlanmasının progresyon riskini 3.4 kat azalttığ $(\mathrm{p}=<0.001)$, LVİ varlığının da progresyon riskini 1.9 kat arttırdığ $(p=0.004)$ gözlendi (Tablo 6). Genel sağkalım açısından ise tek prognostik faktörün cerrahi sınır negatifliği olduğu gözlendi. Cerrahi sınır negatifliği ölüm riskini 2.4 kat azaltmaktaydı ( $p=<0.001$, Tablo 6). Lenfovasküler invazyon sadece PS için, cerrahi sınır negatifliği ise hem PS hem GS için prognostik faktör olarak belirlendi. 


\begin{tabular}{|c|c|c|c|}
\hline \multicolumn{4}{|c|}{ Orijinal Makale } \\
\hline & $\begin{array}{l}\text { Adenokarsino } \\
\mathrm{m}\end{array}$ & $25^{*}$ & $\% 13.7$ \\
\hline & $\begin{array}{l}\text { Skuamoz } \\
\text { hücreli }\end{array}$ & 153 & $\% 84.1$ \\
\hline & $\begin{array}{l}\text { Adenoskuam } \\
\mathrm{oz}\end{array}$ & 4 & $\% 2.2$ \\
\hline \multicolumn{4}{|l|}{ Lokalizasyon } \\
\hline & Üst & 27 & $\% 14.8$ \\
\hline & Orta & 42 & $\% 23.1$ \\
\hline & Alt uç & 113 & $\% 62.1$ \\
\hline \multicolumn{4}{|c|}{ Diferansiasyon } \\
\hline & İyi & 21 & $\% 11.5$ \\
\hline & Orta & 95 & $\% 52.2$ \\
\hline & $\mathrm{Az}$ & 56 & $\% 30.8$ \\
\hline \multicolumn{4}{|c|}{$\begin{array}{l}\text { Klinik evreleme } \\
\text { (Görüntüleme ile) }\end{array}$} \\
\hline & Evre 2 & 12 & $\% 6.6$ \\
\hline & Evre 3 & 138 & $\% 75.8$ \\
\hline & Evre 4 & 32 & $\% 17.5$ \\
\hline \multicolumn{4}{|c|}{$\begin{array}{l}\text { Direk operasyon sonras1 } \\
\text { evreleme }\end{array}$} \\
\hline & Evre 2 & 9 & $\% 4.9$ \\
\hline & Evre 3 & 12 & $\% 6.6$ \\
\hline \multicolumn{4}{|c|}{ Adjuvan kemo(radyoterapi) } \\
\hline & Var & 11 & $\% 6.1$ \\
\hline & Yok & 171 & $\% 93.9$ \\
\hline \multicolumn{4}{|c|}{ Neoadjuvan kemoterapi } \\
\hline & Var & 5 & $\% 2.7$ \\
\hline & Yok & 177 & $\% 97.3$ \\
\hline \multicolumn{4}{|c|}{ Neoadjuvan kemoradyoterapi } \\
\hline & Var & 56 & $\% 30.8$ \\
\hline
\end{tabular}




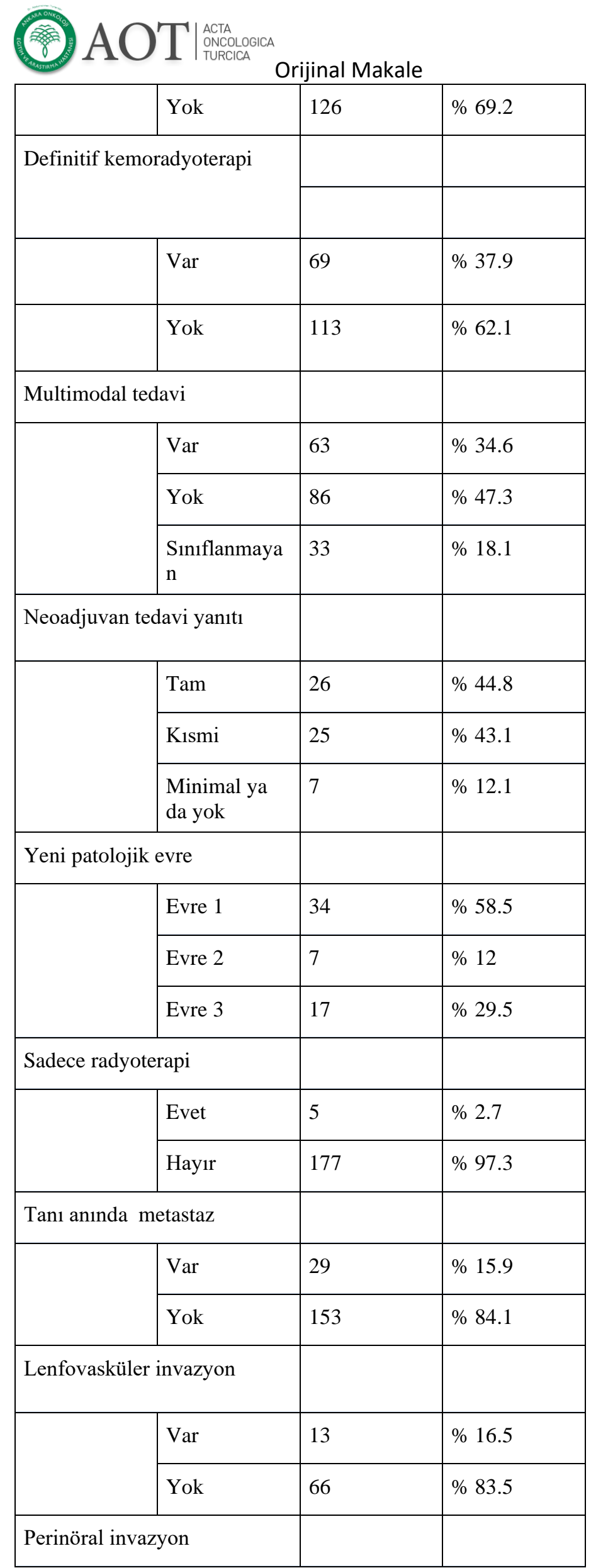




\begin{tabular}{|c|c|c|c|}
\hline & Var & 9 & $\% 11.4$ \\
\hline & Yok & 70 & $\% 88.6$ \\
\hline \multicolumn{4}{|l|}{ Rezeksiyon tipi } \\
\hline & R0 & 72 & $\% 91.1$ \\
\hline & R1 & 7 & $\% 8.9$ \\
\hline
\end{tabular}

*Adenokarsinomların \%92'si (n:23) özefagus alt uçta gözlenmiştir.

R0: Cerrahi sınır negatif R1: Mikroskopik cerrahi sınır pozitif

Tablo 2: Sistemik tedavi ve radyoterapi yan etkileri

\begin{tabular}{|c|c|c|c|c|}
\hline & Yok & Derece 1 & Derece 2 & Derece 3 ve üzeri \\
\hline Bulant1-kusma & $74 \quad(\%$ 40.7) & $87(\% 47.8)$ & $19(\%$ 10.4) & $2(\% 1.1)$ \\
\hline Nötropeni & $121(\% 66.5)$ & $43(\% 23.6)$ & $10(\% 5.5)$ & $8(\% 4.4)$ \\
\hline Trombositopeni & $155(\% 85.2)$ & $15(\%$ 18.2) & $9 \quad(\% 4.9)$ & $3(\%$ 1.6) \\
\hline Diare & $162(\% 89)$ & $19(\%$ 10.4) & $1 \quad(\% 0.5)$ & - \\
\hline Mukozit-Stomatit & $74 \quad(\% 40.7)$ & $85(\% 46.7)$ & $23(\%$ 12.6) & - \\
\hline Oral alım bozukluğu & $74 \quad(\% 40.7)$ & $108(\% 59.3)^{*}$ & & \\
\hline Nefrotoksisite & $177(\% 97.3)$ & $5(\% 2.7)^{*}$ & & \\
\hline Hepatotoksisite & $171(\% 93.9)$ & $11(\% 6.1)^{*}$ & & \\
\hline
\end{tabular}

Tablo 3. Multimodal tedavi açısından hasta gruplarının karşılaştırılması

\begin{tabular}{|l|l|l|l|l|}
\hline & & $\begin{array}{l}\text { Multimodal tedavi } \\
\text { alan grup } \\
\mathrm{n}=63\end{array}$ & $\begin{array}{l}\text { Multimodal tedavi } \\
\text { almayan grup } \mathrm{n}=86\end{array}$ & P değeri \\
\hline Yaş & Median & & & \\
\hline
\end{tabular}




\section{Orijinal Makale}

\begin{tabular}{|c|c|c|c|c|}
\hline \multirow[t]{2}{*}{ Cinsiyet } & Kadın & $23(\% 36.5)$ & $40(\%$ 46.5) & 0.146 \\
\hline & Erkek & $40(\%$ 63.5) & $46(\% 53.5)$ & \\
\hline \multirow[t]{2}{*}{ Sigara } & İçen & $39(\% 61.9)$ & $46(\% 53.4)$ & 0.255 \\
\hline & İçmeyen & $24(\% 38.1)$ & $40(\%$ 46.6) & \\
\hline \multirow{2}{*}{ Kronik Alkol } & Alan & $5 \quad(\%$ 7.9) & $4 \quad(\% 4.6)$ & 0.342 \\
\hline & Almayan & $58(\% 92.1)$ & $82(\% 95.4)$ & \\
\hline \multirow[t]{2}{*}{ Komorbidite } & Var & $18(\% 28.5)$ & $24(\% 27.9)$ & 0.536 \\
\hline & Yok & $45(\% 71.5)$ & $62(\% 72.1)$ & \\
\hline \multirow[t]{2}{*}{ Ailede malignite } & Var & $19(\% 30.1)$ & $18(\% 20.9)$ & 0.137 \\
\hline & Yok & $44(\%$ 69.9) & $68(\% 79.1)$ & \\
\hline \multirow[t]{3}{*}{ Tümör grad } & İyi diferansiye & $13(\% 20.6)$ & $6(\%$ 6.9) & 0.014 \\
\hline & Orta diferansiye & $38(\%$ 60.0) & $51(\% 59.3)$ & \\
\hline & Az diferansiye & $12(\%$ 19.4) & $29(\% 33.8)$ & \\
\hline \multirow[t]{3}{*}{ Lokalizasyon } & Üst & $1(\% 1.7)$ & $25(\% 29.0)$ & $<0.001$ \\
\hline & Orta & $11(\%$ 17.4) & $26(\% 30.2)$ & \\
\hline & Alt & $51(\% 80.9)$ & $35(\% 40.8)$ & \\
\hline \multirow[t]{2}{*}{ Preklinik evre } & Evre 2 & $6(\% 9.5)$ & $6(\%$ 6.9) & 0.489 \\
\hline & Evre 3 & $57(\% 90.5)$ & $80(\%$ 93.1) & \\
\hline \multirow[t]{2}{*}{ Histolojik Tip } & Adenokarsinom & $9(\%$ 14.2) & $8(\%$ 9.3) & 0.597 \\
\hline & Skuamoz hücreli & $52(\% 82.5)$ & $76(\% 88.3)$ & \\
\hline
\end{tabular}


Tablo 4: Tek değişkenli analizlerde progresyonsuz sağkalım sürelerinin karşılaştırılması

\begin{tabular}{|c|c|c|c|c|}
\hline & & Ortanca (ay) & GA $\% 95$ & $P$ değeri \\
\hline \multirow[t]{2}{*}{ Cinsiyet } & Erkek & 16.2 & $12.2-20.3$ & 0.171 \\
\hline & Kadın & 20.4 & 8.7- 31.3 & \\
\hline \multirow[t]{3}{*}{ Histolojik tip } & Adenokarsinom & 20.6 & $6.8-34.5$ & 0.965 \\
\hline & Skuamozhücreli & 37.3 & $11.1-20.7$ & \\
\hline & Adenoskuamoz & 21.4 & 5.4- 26.6 & \\
\hline \multirow[t]{3}{*}{ Tümör lokalizasyonu } & Üst & 16.2 & 4.9- 27.6 & 0.960 \\
\hline & Orta & 14.8 & 8.4- 21.2 & \\
\hline & Alt uç & 18.9 & $13.1-24.7$ & \\
\hline \multirow{3}{*}{$\begin{array}{l}\text { Diferansiasyon } \\
\text { derecesi }\end{array}$} & İyi & 34.3 & 22.2- 46.4 & 0.005 \\
\hline & Orta & 18.3 & $11.8-24.8$ & \\
\hline & $\mathrm{Az}$ & 9.5 & $6.7-12.2$ & \\
\hline \multirow{2}{*}{$\begin{array}{l}\text { Multimodal tedavi } \\
\text { varlığ } 1\end{array}$} & Var & 28.9 & 24.4- 33.4 & $<0.001$ \\
\hline & Yok & 14.8 & 8.3- 21.4 & \\
\hline \multirow{2}{*}{$\begin{array}{l}\text { Lenfovasküler } \\
\text { invazyon }\end{array}$} & Yok & 30.7 & $19.2-42.1$ & $<0.001$ \\
\hline & Var & 16.5 & $11-22$ & \\
\hline \multirow[t]{2}{*}{ Perinöral invazyon } & Yok & 27.6 & 20.8- 34.4 & 0.075 \\
\hline & Var & 19.8 & $12.2-27.4$ & \\
\hline \multirow[t]{2}{*}{ Rezeksiyon tipi } & R0 & 29.4 & $24.6-34.2$ & $<0.001$ \\
\hline & $\mathrm{R} 1$ & 9.9 & 4.8- 14.9 & \\
\hline
\end{tabular}




\begin{tabular}{|l|l|l|l|l|}
\hline \multirow{2}{*}{$\begin{array}{l}\text { Neoadjuvan tedavi } \\
\text { yanıtı }\end{array}$} & Var & 30.1 & $22.9-38.5$ & 0.042 \\
\cline { 2 - 5 } & Yok & 12.9 & $12.7-13.1$ & \\
\hline $\begin{array}{l}\text { Tanıda metastaz } \\
\text { varlığ }\end{array}$ & Yok & 20.6 & $13.9-27.4$ & $<0.001$ \\
\cline { 2 - 5 } & Var & 7.6 & $6.1-9.1$ & \\
\hline
\end{tabular}

R0;cerrahi sınır negatif , R1;mikroskobik olarak cerrahi sınır pozitif GA; Güven aralığı

Tablo 5: Tek değişkenli analizlerde genel sağkalım sürelerinin karşılaştırılması

\begin{tabular}{|c|c|c|c|c|}
\hline & & Ortanca (ay) & GA $\% 95$ & P değeri \\
\hline \multirow[t]{2}{*}{ Cinsiyet } & Erkek & 26.4 & $21-31.7$ & 0.027 \\
\hline & Kadın & 45 & 20.4- 69.6 & \\
\hline \multirow[t]{3}{*}{ Histolojik tip } & Adenokarsinom & 28.8 & 21.2- 36.4 & 0.330 \\
\hline & Skuamozhücreli & 28.6 & $21.7-35.5$ & \\
\hline & Adenoskuamoz & 17.4 & - & \\
\hline \multirow{3}{*}{$\begin{array}{l}\text { Tümör } \\
\text { lokalizasyonu }\end{array}$} & Üst & 31.4 & $16.5-46.2$ & 0.834 \\
\hline & Orta & 24.8 & $16.3-33.3$ & \\
\hline & Alt uç & 28.9 & 19.4- 38.4 & \\
\hline \multirow{3}{*}{$\begin{array}{l}\text { Diferansiasyon } \\
\text { derecesi }\end{array}$} & İyi & 41 & $22.1-59.9$ & $<0.001$ \\
\hline & Orta & 35.2 & $16.2-54.2$ & \\
\hline & $\mathrm{Az}$ & 14.8 & $9.7-20$ & \\
\hline \multirow{2}{*}{$\begin{array}{l}\text { Multimodal tedavi } \\
\text { varlığ } 1\end{array}$} & Var & 47.6 & $29.3-65.8$ & $<0.001$ \\
\hline & Yok & 28.1 & $20.1-36.1$ & \\
\hline \multirow{2}{*}{$\begin{array}{l}\text { Lenfovasküler } \\
\text { invazyon }\end{array}$} & Yok & 57.7 & $33.8-81.6$ & 0.138 \\
\hline & Var & 33.1 & $21.5-44.6$ & \\
\hline
\end{tabular}




\begin{tabular}{|l|l|l|l|l|}
\hline \multirow{2}{*}{ Perinöral invazyon } & Yok & 49.2 & $33.1-65.3$ & 0.624 \\
\cline { 2 - 5 } & Var & 33.1 & $21.2-44.9$ & \\
\hline Rezeksiyon tipi & R0 & 57.7 & $28.9-86.4$ & $<0.001$ \\
\cline { 2 - 5 } & R1 & 15.4 & $10.2-20.5$ & \\
\hline \multirow{2}{*}{$\begin{array}{l}\text { Neoadjuvan tedavi } \\
\text { yanitı }\end{array}$} & Var & 62.7 & $59.5-92.8$ & 0.005 \\
\cline { 2 - 5 } & Yok & 26.4 & $16.6-42.7$ & \\
\hline $\begin{array}{l}\text { Tanıda metastaz } \\
\text { varlığ }\end{array}$ & Yok & 33.9 & $26-41.8$ & $<0.001$ \\
\cline { 2 - 5 } & Var & 11.6 & $8-15.2$ & \\
\hline
\end{tabular}

R0;cerrahi sınır negatif, R1;mikroskobik olarak cerrahi sınır pozitif; GA; Güven aralığı

Tablo 6: Progresyonsuz sağkalım ve Genel sağkalım için çok değişkenli cox regresyon analizi

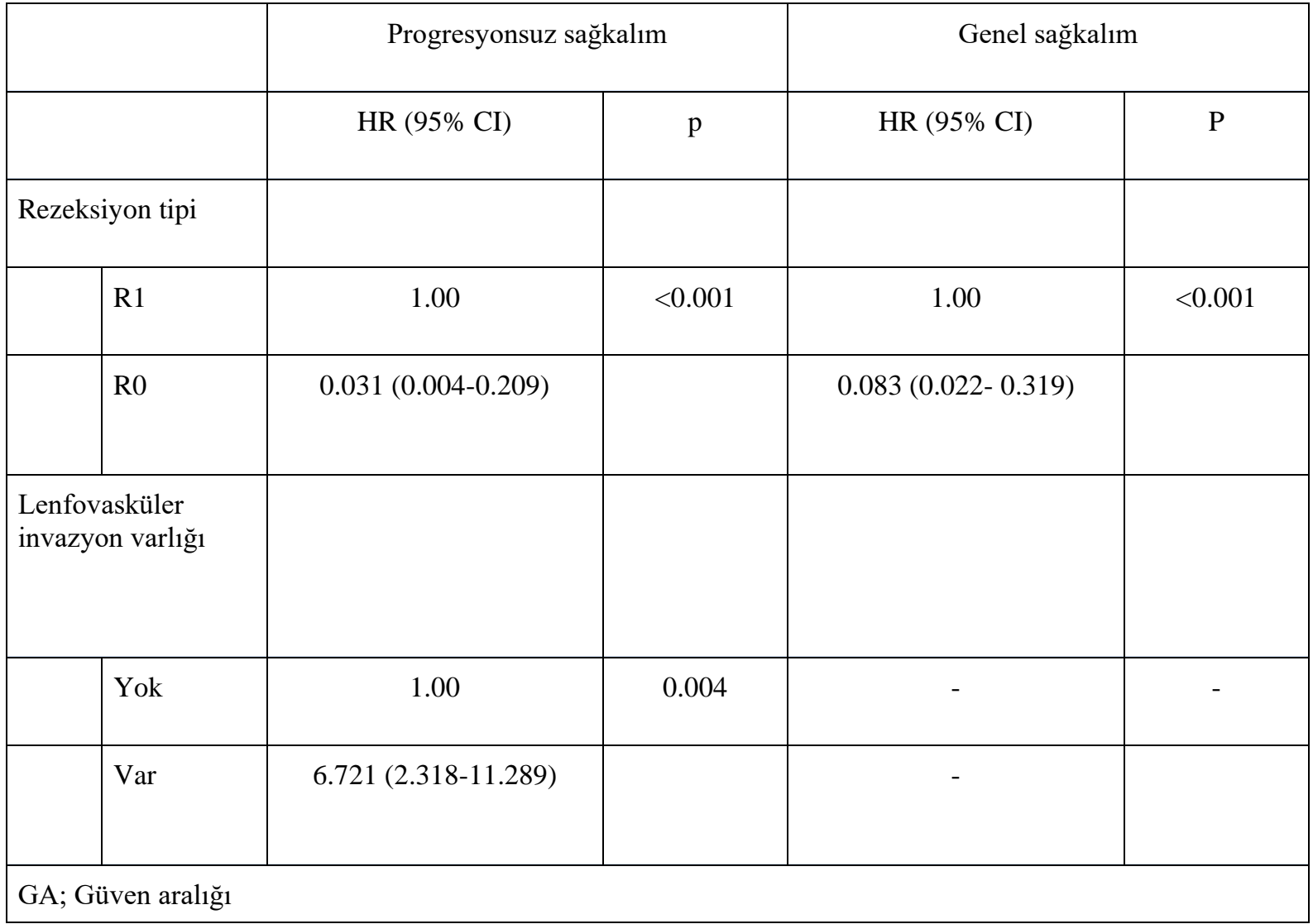




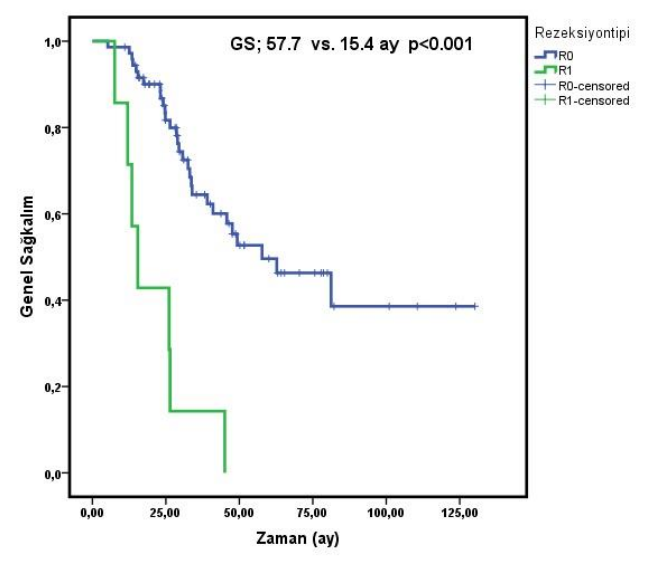

Figür 1. Rezeksiyon tipine göre GS eğrileri

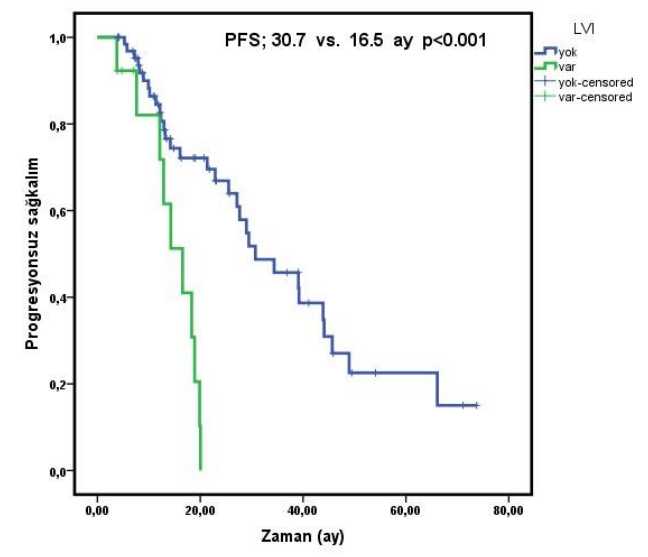

Figür 2. Rezeksiyon tipine göre PS eğrileri

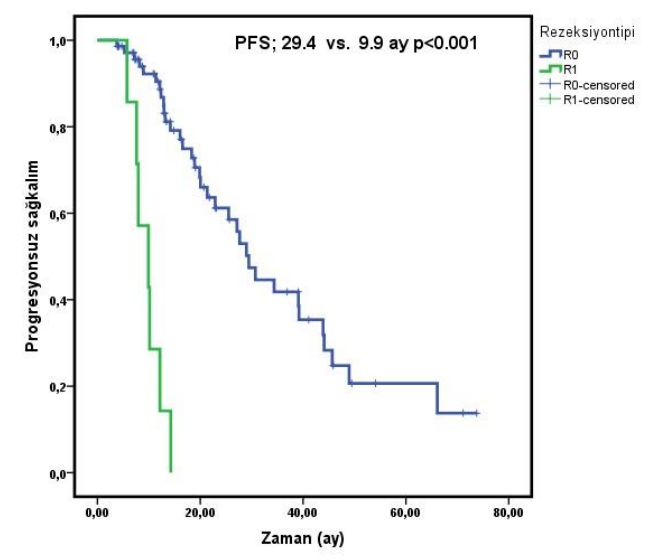

Figür 3. Lenfovasküler invazyon varlığına göre PS eğrileri

\section{TARTIŞMA}

Çalışmamızda tek merkez verisi olarak özefagus kanseri tanısı ile takipli hastaların genel demografik, klinik, prognostik ve sağkalım verilerini inceledik. Bölümümüzde takipli, tüm özefageal seviyelerde ve tüm evrelerde sistemik tedavi alan heterojen bir grup hastayı gözlemsel olarak değerlendirmeyi amaçladık.

Hastaların demografik özelliklerine bakıldığında literatür ile uyumlu olarak çoğunluğun 50-60 yaş arasında olduğu ve etiyolojik faktörler açısından sigara içme oranını yüksek olduğu saptanmıştır $(2,6)$. Retrospektif çalışma olması itibariyle obezite, diet alışkanlığı, reflü bulguları gibi risk faktörleri değerlendirilememiştir. Kronik obtrüktif akciğer hastalığ komorbid hastalıklar daha sık skuamoz hücreli kansere eşlik ederken diabet, hipertansiyon ve koroner arter hastalığ 1 adenokanserlerle birlikte daha s1k görülür (27). Bizim hasta grubumuzun yaklaş1k dörtte birinde (\%26.9) komorbidite gözlenmiş ve en sik hipertansiyona (\%48.9) rastlanmıştır. Tedavi başlangıcında nütrisyonel ölçüm yapılmadığı için malnutrisyon durumları bilinmemektedir.

Özefagus kanseri histolojik iki alt tipten oluşur. Son y1llarda adenokanser sıklığı artış gösterse de skuamoz hücreli kanser en sik görülen histolojik tiptir. Adenokanser daha çok alt uçta görülürken skuamoz hücreli tip her üç bölgede de bulunur (27). Bizim hasta grubumuzda da skuamoz hücreli tip en sık görülen alt tip olarak her üç bölgede de gözlenmiş ve adenokanserlerin \%92'si alt uçta saptanmıştır.

Tedavi öncesi evreleme için konvansiyonel tomografilerin PET BT ile desteklenmesi hem uzak metastaz hem de nodal tutulum olan bölgelerin saptanmas1 açısından önemlidir. Özellikle tomografilerinde uzak metastazı olmayan hastalar için doğru evrelemeyi sağlar (10). Hastalarımızda tedavi öncesi PET BT çekim oran1 \%89.6 olup PET BT çekilmeyen hastalar tanıda metastatiktir. Uzak metastaz bölgesi olmayan hastalarda tedavi seçimini etkileyecek olan tümör derinliği ve lokorejyonel nod tutulumu gibi prognostik faktörlerin 


\section{Orijinal Makale}

değerlendirilmesi için EUS planlamalıdır (2, 11). Bölgemizde EUS yapan merkezlerin azlığ1 nedeniyle tedavi öncesi EUS çekim oranımız düşüktür (\%7.1). Anatomik bölge açısından üst özefagus tümörleri için cerrahi tedavinin mortalitesi ve morbiditesi göz önüne alındığında definitif kemoradyoterapi ile tedavisi ön plandadır. Platin bazlı kemoterapi ile küratif doz radyoterapi (50-70 Gy) birlikte uygulanır (8). Çalışmamıza dahil edilen üst özefageal kanserli hastaların \% 89'una (n: 24) definitif kemoradyoterapi uygulanmıştır. İki hasta (\%7.4) opere edilmiştir ve 1 (3.6) hasta metastatik hastalığa sahiptir. Definitif kemoradyoterapi uygulanan hastalara en az 50 Gy radyoterapi verilmiştir.

Erken evre olmayan lokal ileri rezeke edilebilen özefagus kanserlerinin tedavisine neoadjuvan kemoradyoterapi eklenmesi ile dramatik sağkalım farkı CROSS çalışması ile elde edilmiştir (13). Özefagusun çoğunluğu alt uçtan olmak üzere her seviyesinden ve yine çoğunluğu adenokarsinom olmak üzere tüm histolojik alt gruplardan hastanın alındı ̆̆1 randomize prospektif Faz III bu çalışmada radyoterapi eş zamanlı karboplatin (2 AUC) ve paklitaksel (50mg/m2/hafta) verilmiştir. Tolere edilebilir düşük dereceli yan etkilerin yanında neoadjuvan kemoradyoterapi kolunda \%92 cerrahi sınır negatifliği (R0) ve \% 29'unda patolojik tam yanıt elde edilmiştir. Patolojik tam yanıt skuamoz hücreli grupta daha fazladır (\%49 vs \%23, p=0.008). Yalnızca cerrahi uygulanan kolda \%69 cerrahi sınır negatifliği $(\mathrm{p}<0.001)$ sağlanmıştır. İki grup arasındaki sağkalım farkı iki katından fazladır (49.4 vs 24.0) (13). Çalışma grubumuza bakıldığında neoadjuvan kemoradyoterapi verilen hastaların \%82.3'üne karboplatin paklitaksel tedavisi verilmiştir. Patolojik tam yanıt oran $1 \% 44.8$ ve bu hastaların \%84.6's1 (n:22) skuamoz hücreli karsinom tipindedir. Tam ve kısmi yanıt alınan tüm hastalara bakıldığında tümör lokalizasyonu \%80.4 alt uçtadır. Neoadjuvan kemoradyoterapi yanitı (k1smi ve tam) alınan tüm hastalarda cerrahi sınır negatifliği (R0) oranı \%98.1'dir. Sadece cerrahi yapılan 21 hastamızın R0 oranı \%81'dir. Direk cerrahi yapılan grup ile neoadjuvan kemoradyoterapi verilen grup arasındaki sayısal dengesizlik nedeniyle istenen karşılaştırmalar yapılamamıştır. Neoadjuvan kemoradyoterapi grubunda CROSS çalışması ile uyumlu olarak yüksek patolojik tam yanıt ve R0 oranları elde edilmiştir. Ayrıca tek değişkenli analizlerde neoadjuvan tedavi yanitı ve multimodal tedavi varlığı ile hem GS hem de PS avantajı sağlanmıştır.

Preoperatif neoadjuvantedavi sonrası rezidü nodal hastalık varlığında postoperatif adjuvan kemoterapinin sağkalım avantaj1 gösterilmiştir (25, 26, 28). Fakat çalışmamızda neoadjuvan tedavi sonrası adjuvan tedavi verilen hasta sayısının çok küçük olması nedeniyle istatistik yapılamamıştır. $\mathrm{Bu}$ hastalar multimodal grupta incelenmiştir.

Özefagus

kanserinde sağkalımı etkileyen prognostik faktörler şimdiye kadar yapılan araştırmalarda yaş, performans skoru, evre, tümör derecesi, neoadjuvan tedavi, tümör invazyon derinliği, lenf nodu tutulumu, LVI ve cerrahi sinır negatifliği olarak bulunmuştur (29-31). Neoadjuvan kemoterapi alan 400 hastalık bir çalışmada LVİ ve cerrahi sınır negatifliği kuvvetli prognostik faktör olarak bulunmuştur (31). Bizim çalışmamızda da cerrahi sınır negatifliği hem GS' 1 hem de PS '1, LVİ ise PS'1 etkileyen anlamlı prognostik faktörler olarak bulunmuştur.

Çalışmamızın retrospektif ve heterojen bir grup hastadan oluşması en önemli k1sıtlılığıdır. Uygulanan tedavilerin farklılı̆̆ nedeniyle tam olarak homojen bir grup oluşturulamamıştır. Retrospektif olması nedeniyle risk faktörleri ile ilgili geniş bilgi sahibi olunamamıştır. Bazı küçük grupların varlığı nedeniyle literatürle uyum araştırılamamıştır. $\mathrm{Bu}$ nedenle 182 hastanın gözlemsel verisi paylaşılmıştır.

\section{SONUÇ}

Sonuç olarak tek merkeze ait veriler sunulmuş ve oluşturulan alt gruplarda tedavi yanıtı, rezeksiyon tipi, histolojik alt tip ve tümör lokalizasyonu ile ilgili literatür ile uyumlu bulgular elde edilmiştir. Tek değişkenli analizlerde tümör diferansiyasyon derecesi, multimodal tedavi varlığı, rezeksiyon tipi, neoadjuvan tedavi yanıtı ve tanıda metastaz varlığının sağkalımları etkilediği çok değişkenli analizlerde ise LVİ ve cerrahi sınır negatifliğinin kuvvetli prognostik faktörler olduğu gösterilmiştir. Daha fazla hasta sayısına, homojen gruplar sağlanarak prognoza etki eden faktörlerin daha ayrıntılı 


\section{Orijinal Makale}

incelenebilmesi için ihtiyaç vardır.

Çıkar çatışması: Yazarların hiçbir çıkar çatışması yoktur.

\section{REFERANSLAR}

1. Domper Arnal MJ, Ferrandez Arenas A, Lanas Arbeloa A. Esophageal cancer: Risk factors, screening and endoscopic treatment in Western and Eastern countries. World J Gastroenterol. 2015;21:7933-43.

2. Short MW, Burgers KG, Fry VT. Esophageal Cancer. Am Fam Physician. 2017;95:22-28.

3. Pennathur A, Gibson MK, Jobe BA, Luketich JD. Oesophageal carcinoma. Lancet. 2013;381:400-12.

4. Huang FL, Yu SJ. Esophageal cancer: Risk factors, genetic association, and treatment. Asian J Surg. 2018;41:210-15.

5. Enzinger PC, Mayer RJ. Esophageal cancer. N Engl J Med. 2003;349:2241-52.

6. Engel LS, Chow WH, Vaughan TL, et al. Population attributable risks of esophageal and gastric cancers. J Natl Cancer Inst. 2003;95:1404-13.

7. Sharma P, McQuaid K, Dent J, et al. A critical review of the diagnosis and management of Barrett's esophagus: the AGA Chicago Workshop. Gastroenterology. 2004;127:310-30.

8. Zhang P, Xi M, Zhao L, et al. Clinical efficacy and failure pattern in patients with cervical esophageal cancer treated with definitive chemoradiotherapy. Radiother Oncol. 2015;116:257-61.

9. Cavallin F, Scarpa M, Cagol M, et al. Esophageal Cancer Clinical Presentation: Trends in the Last 3 Decades in a Large Italian Series. Ann Surg. 2018;267:99-104.

10. Meltzer CC, Luketich JD, Friedman D, et al. Whole-body FDG positron emission tomographic imaging for staging esophageal cancer comparison with computed tomography. Clin Nucl Med. 2000;25:882-7.

11. Hofstetter W, Swisher SG, Correa AM, et al. Treatment outcomes of resected esophageal cancer. Ann Surg. 2002;236:376-84; discussion 84-5.

12. Eren T, İmamoğlu Gİ, Yildiz F, et al. Local treatment options for management of loco-regional esophageal squamous cell carcinoma. RJMM. 2019;122:36.

13. van Hagen P, Hulshof MC, van Lanschot JJ, et al. Preoperative chemoradiotherapy for esophageal or junctional cancer. N Engl J Med. 2012;366:2074-84.

14. Urba SG, Orringer MB, Turrisi A, Iannettoni M, Forastiere A, Strawderman M. Randomized trial of preoperative chemoradiation versus surgery alone in patients with locoregional esophageal carcinoma. J Clin Oncol. 2001;19:305-13.

15. Burmeister BH, Smithers BM, Gebski V, et al. Surgery alone versus chemoradiotherapy followed by surgery for resectable cancer of the oesophagus: a randomised controlled phase III trial. Lancet Oncol. 2005;6:659-68.

16. Lee JL, Park SI, Kim SB, et al. A single institutional phase III trial of preoperative chemotherapy with hyperfractionation radiotherapy plus surgery versus surgery alone for resectable esophageal squamous cell carcinoma. Ann Oncol. 2004;15:947-54.
17. Mariette C, Dahan L, Mornex F, et al. Surgery alone versus chemoradiotherapy followed by surgery for stage I and II esophageal cancer: final analysis of randomized controlled phase III trial FFCD 9901. J Clin Oncol. 2014;32:2416-22.

18. Bosset JF, Gignoux M, Triboulet JP, et al. Chemoradiotherapy followed by surgery compared with surgery alone in squamous-cell cancer of the esophagus. N Engl J Med. 1997;337:161-7.

19. Tepper J, Krasna MJ, Niedzwiecki D, et al. Phase III trial of trimodality therapy with cisplatin, fluorouracil, radiotherapy, and surgery compared with surgery alone for esophageal cancer: CALGB 9781. J Clin Oncol. 2008;26:1086-92.

20. Tulay E, Karacin C, Gokhan U, et al. Efficacy of the Combination of Modified Docetaxel, Cisplatin and Fluorouracil in Locally Advanced Gastric Cancer: Evaluation of Real-Life Outcomes. UHOD.29:001-09.

21. Sjoquist KM, Burmeister BH, Smithers BM, et al. Survival after neoadjuvant chemotherapy or chemoradiotherapy for resectable oesophageal carcinoma: an updated meta-analysis. Lancet Oncol. 2011;12:681-92.

22. Stahl M, Stuschke M, Lehmann N, et al. Chemoradiation with and without surgery in patients with locally advanced squamous cell carcinoma of the esophagus. J Clin Oncol. 2005;23:2310-7.

23. Rice TW, Adelstein DJ, Chidel MA, et al. Benefit of postoperative adjuvant chemoradiotherapy in locoregionally advanced esophageal carcinoma. J Thorac Cardiovasc Surg. 2003;126:1590-6.

24. Bedard EL, Inculet RI, Malthaner RA, Brecevic E, Vincent M, Dar R. The role of surgery and postoperative chemoradiation therapy in patients with lymph node positive esophageal carcinoma. Cancer. 2001;91:2423-30.

25. Burt BM, Groth SS, Sada YH, et al. Utility of Adjuvant Chemotherapy After Neoadjuvant Chemoradiation and Esophagectomy for Esophageal Cancer. Ann Surg. 2017;266:297-304.

26. Mokdad AA, Yopp AC, Polanco PM, et al. Adjuvant Chemotherapy vs Postoperative Observation Following Preoperative Chemoradiotherapy and Resection in Gastroesophageal Cancer: A Propensity Score-Matched Analysis. JAMA Oncol. 2018;4:31-38.

27. Allum WH, Blazeby JM, Griffin SM, et al. Guidelines for the management of oesophageal and gastric cancer. Gut. 2011;60:1449-72.

28. Glatz $\mathrm{T}$, Bronsert $\mathrm{P}$, Schafer $\mathrm{M}$, et al. Perioperative platin-based chemotherapy for locally advanced esophagogastric adenocarcinoma: Postoperative chemotherapy has a substantial impact on outcome. Eur J Surg Oncol. 2015;41:1300-7.

29. Wu H, Liu C, Xu M, Guo M, Xu S, Xie M. Prognostic value of the number of negative lymph nodes in esophageal carcinoma without lymphatic metastasis. Thorac Cancer. 2018;9:1129-35.

30. Tonoiso $\mathrm{C}$, Ikushima $\mathrm{H}$, Kubo A, et al. Clinical outcomes and prognostic factors of definitive radiotherapy for esophageal cancer. $\mathrm{J}$ Med Invest. 2019;66:99-105.

31. Davies AR, Gossage JA, Zylstra J, et al. Tumor stage after neoadjuvant chemotherapy determines survival after surgery for adenocarcinoma of the esophagus and esophagogastric junction. J Clin Oncol. 2014;32:2983-90. 